\title{
Effect of Combined Oral Contraception on Coagulation Profiles in Women Attending Fertility Control Clinic in Baqubah City- Iraq
}

\author{
Sawsan T. Salman* \\ Areej A. Hussein* \\ Raakad K. Saadi**
}

\author{
FICMS, CABOG \\ PhD \\ FICMS
}

\section{Abstract: \\ JFac Med Baghdad 2018; Vol.60, No .1 Receive Oct. 2017 Accepted Dec. 2017}

Background: Use of oral contraception has been associated with an increased abnormalities of lipid and carbohydrate metabolism as well as hemostatic variables at baseline (increased plasma levels of factor VII, factor X, fibrinogen and of D-dimers).

Objectives: To evaluate the effect of oral contraceptive pills (combined pills) on coagulation tests,prothrombin time (PT), activated partial thromboplastin time (APTT), and fibrinogen level.

Patients and methods: This is a descriptive cross sectional study which was conducted in fertility control clinic in Al-Batool Teaching Hospital for Maternity and Children in Baqubah city, during the period from December 2015 to October 2016. Eighty eight women were enrolled in this study according to inclusion criteria, 63 women were use contraceptive pills(study group) and other 25 females not taken these pills (control group), prothrombin time, activated partial thromboplastin time and fibrinogen level measured by using the coagulometer instrument.

Results: The mean age was 29.89 and 30.89 years for all participants (subject and control) it was (range 20-45). The results of cases revealed that PT $=12.89$ seconds, APTT $=30.45$ seconds, and fibrinogen level $=2.18 \mathrm{~g} / \mathrm{l}$ while the results of control group revealed that $\mathrm{PT}=11.92$ seconds, APTT= 29.85 seconds and fibrinogen level $=2.24 \mathrm{~g} / \mathrm{l}$. Overall no significant variations were noticed in these parameters with $\mathrm{P}$ value $>0.05$ also no significant changes were noticed between age groups, duration of oral contraceptives and some clinical parameters.

Conclusion: Effect of combined oral contraceptives use on prothrombin time, activated partial thromboplastin time and fibrinogen levels are minor compared with control group.

Key word: Oral contraception, estrogen,progestagens, thrombosis, blood coagulation.

\section{Introduction}

Most oral contraceptives contain an estrogen and a progestagen (monophasic preparations). In biphasic and triphasic combinations, the content of the pills during one cycle varies, with more estrogen in the early phase of the cycle and more progestagen in the later phase of the cycle [1]. Combined oral contraceptives (COCs) represent one of the most commonly prescribed contraceptive methods and are used by more than 100 million women worldwide [2]. Several studies have shown that women taking combined oral contraceptives show changes in haemostasis. The plasma concentrations of the coagulation factors I (fibrinogen), II, VII, IX, X, and XII have consistently been reported to increase [3]. Together with an associated decrease in antithrombin III concentration [3][4]. These changes may predispose to venous thromboembolism, especially if not balanced by an increase either in fibrinolytic activity or of other inhibitory proteins of the coagulation cascade, such as protein C. Major

* Dept. of Obstetrics and Gynecology, College of Medicine, University of Diyala .

Email:Areej@medicine.uodiyala.edu.iq.

** Dept. of Microbiology, College of Medicine University of Diyala. surgery is a recognized risk factor for venous thromboembolism, but there is debate as to whether use of the combined pill at the time of operation increases the risk further [5]. Most surgeons would advise that the combined oral contraceptive should be stopped for at least four to six weeks before major surgery [6]. Epidemiological studies indicate that oral contraceptives use increases the absolute risk of venous thrombosis (VT) from 0.8 per 10,000 women per year among premenopausal women not using OC to 3.0 per 10,000 per year among OC users [7]. These numbers indicate a low absolute risk even for oral contraceptives users. Nevertheless, because OC are so widely used, they are responsible for a large part, if not the majority, of all venous thrombosis in young women [8]. Due to the observed differences in the risk of VT induced by OC containing the same dose of estrogen but different progestogen compounds, the prothrombotic effect of the pill was considered to be not strictly dependent on the dose of estrogen but rather on the "total estrogenicity" of the formulation. The "total estrogenicity" rises with increasing dose of estrogen but decreases with increasing antiestrogenic activity of progestogen compound [9]. 
The association between estrogen-containing oral contraceptives (OCs) and venous thromboembolism (VTE) is well established [10]. Until 1995, it was generally thought that the progestogen component of COCs did not contribute to the risk of VTE. However, a number of studies published in late 1995 and early 1996 reported an increased risk of VTE for users of the so-called third-generation COCs containing the progestogens, desogestrel or gestodene, compared with second- generation COCs, containing levonorgestrel [11]. Not all women using OCs develop VT, which implies that women using OCs who develop VT are likely to have an additional risk factor [12]. The purpose of this study was to evaluate the effect of oral contraceptive pills (combined pills) on coagulation tests,prothrombin time, activated partial thromboplastin time and fibrinogen level.

\section{Materials and Methods:}

Study design: This study was design as descriptive cross-sectional study wasconducted in fertility control clinic in Al-Batool Teaching Hospital for Maternity and Children in Baqubah city, during the period from December 2015 to October 2016.

Samples collection: Eighty-eight blood samples were collected from two groups, first one includes 63 women at least 6 months after the oral contraception using microgynon (30 micrograms ethinyloestradiol, 150 micrograms levonorgestrel) and second group consist of 25 women without oral contraception(control), ranging in age from 20 to 45 years. All women were non-smokers. Requesting oral contraception were eligible to participate in this study and the information was arranged in an informative formula sheet which includes age, duration of contraceptive use, parity, blood pressure, hip circumference.

Sample processing: three $\mathrm{ml}$ of all participants were submitted to perform coagulation profile. After the subject had rested for 30 minutes blood was taken by clean venipuncture into $0.106 \mathrm{M}$ trisodium citrate (nine volumes blood to one volume anticoagulant) and immediately centrifuged at $3500 \mathrm{rpm}$ using ordinary centrifuge for 10 minutes, finally the sera were collect and labeled to subsequent analysis. prothrombin time, activated partial thromboplastin timewere determined using standard haematological techniques described by [13]. While clottable fibrinogen was determined by the Clauss assay [14]. Data analysis: Fisher's exact test and t-test were used to obtain statistically significant differences between two groups with $(\mathrm{p}<0.05)$ being considered statistically significant.

\section{Results}

The mean age of the 63 females with contraception use (study group) was 29.89 year, (range 20-47) years and for (control subject) it was 30.89 year (range 20-44) as shown in (table 1). During the study period, 45 women in the study group (71.42\%) were in age group 25-39 also the same age group showed high frequency among control group $14(56 \%)$. The statistical analysis did not reveal any significant differencebetween two groups as shown in table 2

Table (1): Distribution of studied group according to the age.

\begin{tabular}{|c|c|c|c|c|c|}
\hline \multirow{2}{*}{$\begin{array}{l}\text { Studied } \\
\text { groups }\end{array}$} & \multirow[t]{2}{*}{ Number } & \multicolumn{3}{|c|}{ Age/ years } & \multirow{2}{*}{$\begin{array}{l}(\mathrm{t} \text {-test }) / \mathrm{P}- \\
\text { value* }\end{array}$} \\
\hline & & Mean & Mini & Maxi & \\
\hline $\begin{array}{l}\text { Contraception } \\
\text { group }\end{array}$ & 63 & 29.89 & 20 & 47 & $\mathrm{p}<0.05$ \\
\hline Control group & 25 & 30.89 & 20 & 44 & \\
\hline
\end{tabular}

Table (2): Distribution of studied groups according to their age.

\begin{tabular}{|c|c|c|c|}
\hline $\begin{array}{l}\text { Age } \\
\text { (years) }\end{array}$ & Subject & Control & $\begin{array}{l}\text { Comparison } \\
\text { Significance } \\
\text { Chi }^{2} \text {-value } \\
\text { Sig. }\end{array}$ \\
\hline $\begin{array}{l}15-24 \\
\text { years }\end{array}$ & $14(22.22 \%)$ & $6(24 \%)$ & p-value 0.140763 \\
\hline $\begin{array}{l}25-39 \\
\text { years }\end{array}$ & $45(71.42 \%)$ & $14(56 \%)$ & \\
\hline $\begin{array}{l}40-54 \\
\text { years }\end{array}$ & $4(6.34 \%)$ & $5(20 \%)$ & \\
\hline Total & $63(99.98 \%)$ & $25(100 \%)$ & \\
\hline
\end{tabular}

Regarding duration of contraceptive use, most subject used contraceptive more than two years $25(39.68 \%)$ followed by use for $\leq 6$ months (21(33.33\%), 7-12 month $10(15.87 \%)$ and finally less percentage was recorded among group use contraception for $13-18$ month $7(11.11 \%)$ as shown in figure (1).

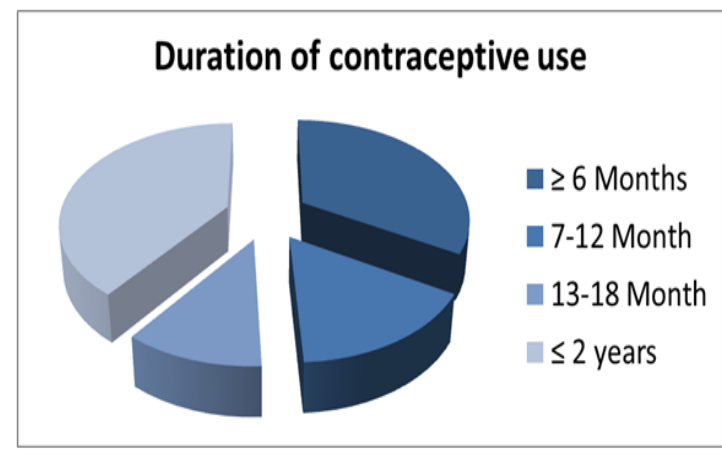

Figure (1): Distribution of women with previous use of COCs (No.=63).

Based on result of statistical analysis there was no significant differences noticed between two groups regarding blood pressure and hip circumference as shown in table (3). 
Table (3): Distribution of studied groups according to clinical characteristics.

\begin{tabular}{|c|c|c|c|}
\hline Parameters & $\begin{array}{l}\text { Subject } \\
\text { Mean }\end{array}$ & $\begin{array}{l}\text { Control } \\
\text { Mean }\end{array}$ & $\begin{array}{l}\text { Comparison } \\
\text { Significance } \\
\text { Chi }^{2} \text {-value } \\
\text { Sig. }\end{array}$ \\
\hline $\begin{array}{l}\text { Systolic blood } \\
\text { pressure }(\mathrm{mmHg})\end{array}$ & 119.33 & 120.80 & $p<0.05$ \\
\hline $\begin{array}{l}\text { Diastolic blood } \\
\text { pressure }(\mathrm{mmHg})\end{array}$ & 76.18 & 77.60 & \\
\hline $\begin{array}{l}\text { Hip circumference } \\
(\mathrm{cm})\end{array}$ & 111.88 & 108.52 & \\
\hline Total & 63 & 25 & \\
\hline
\end{tabular}

Regarding parity, high percent of women were multipara 46(73.01\%) followed by grand multipara $13(20.63 \%)$ also it observed that the low frequency of the study subject was recorded in primiparous $4(6.34 \%)$ but statistically non-significant as shown in figure (2).

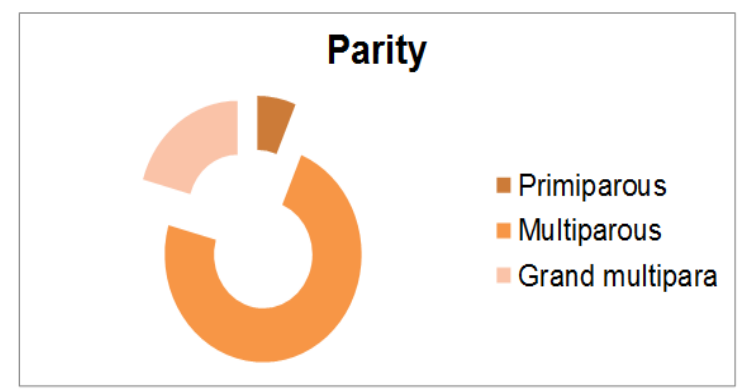

Figure (2): Distribution of women with previous use of COCs according to parity.

The coagulation profile of the women in studied group is shown in table (4) slightly increased in thrombin time and partial thromboplastin time was found in group of contraceptive user compare with control group but statistical non-significant while the plasma level of fibrinogen is elevated in control group but statistical analysis not revealed any significant difference between two groups.

Table (4): Distribution of studied groups according to some haemostatic parameters.

\begin{tabular}{|c|c|c|c|c|c|}
\hline \multirow[t]{2}{*}{ Parameters } & \multicolumn{4}{|l|}{ Subject } & \multirow[t]{2}{*}{ Control } \\
\hline & $\begin{array}{l}\leq 6 \\
\text { months }\end{array}$ & $\begin{array}{l}1 \\
\text { years }\end{array}$ & $\begin{array}{l}1.5 \\
\text { years }\end{array}$ & $\begin{array}{l}\geq 2 \\
\text { years }\end{array}$ & \\
\hline $\begin{array}{l}\text { Prothrombin } \\
\text { time (PT)Sec }\end{array}$ & 12.76 & 12.71 & 13.28 & 12.81 & 11.92 \\
\hline $\begin{array}{l}\text { Partial } \\
\text { thromboplastin } \\
\text { time (PTT) Sec }\end{array}$ & 29.62 & 30.00 & 31.14 & 31.05 & 29.85 \\
\hline $\begin{array}{l}\text { Plasma } \\
\text { fibrinogen level } \\
(\mathrm{g} / \mathrm{l})\end{array}$ & 1.92 & 2.04 & 2.51 & 2.26 & 2.24 \\
\hline Total & 63 & & & & 25 \\
\hline
\end{tabular}

\section{Discussion}

The result of current study showed that mean age were 29.89 and 30.89 for subject and control but without significant difference, this finding was comparable with [15] and with [16] showed 28 and
27.8 years respectively. Another study done by [17] showed lower mean age among women using third generation oral contraceptives in German, and higher than reported by [18] who found that 35.4 and 34.7 mean age for subject and control groups. The changes in the haemostatic system during oral contraceptive use are similar to those seen in younger women using the same preparations [19]. It is thus unlikely that the changes found in the study group will differ greatly in younger women. In current study there is no significant difference was observed between women with oral contraceptive use and control group regardingblood pressure, this result disagree with [20] who found that after one year, blood pressure had risen significantly $(\mathrm{P}<0.05)$ in the 137 women taking ethinyloestradiol plus levonorgestrel (mean systolic and diastolic rises 6.4 and $2.7 \mathrm{mmHg}$ respectively) also disagree with study done by Khaw and Peart, they found (In a survey of 461 women routinely attending family planning clinics those taking oral contraceptives had significantly higher mean systolic and diastolic blood pressures than those using non-hormonal contraception. There appeared to be a dose-response relation of blood pressure to the progestogen component of two generation of contraceptives with an identical $30 \mu$ gethinyloestradiol component. This supports the idea that the progestogen as well as the oestrogen component has an aetiological role in the rise in blood pressure. There was a significant correlation of blood pressure with duration of current use of oral contraceptive but not with total duration of use, the result of this study show significant negative correlation of blood pressure with time since oral contraceptives were last taken. Regarding parity, the result showed that high frequency of participant had multipara 46(73.01\%) followed by grand multipara $13(20.63 \%)$ this result comparable with [22]. Also, may be related with culture of our population so large family size is more common in our population. In the present study, a non-significant increase was found in coagulation parameters in women taking combined oral contraceptive pills compared with control group, this result consistent with study done by LeBlanc and Ami [23]. Also agreed with several studies which have shown that women taking combined oral contraceptives show alteration in coagulation parameters [24-27]. This may be because of type of contraception used by our patient (microgynon) that contain $2^{\text {nd }}$ generation progestin that had less effect and risk on coagulation parameters compared with $3^{\text {rd }}$ generations. The result of this study disagrees with other studies show diverts results such as, ALHusaynee and Muna they found a significant increase in the mean values of (PC), fibrinogen with ( $\mathrm{P}<0.05,<0.05)$ respectively, while the $\mathrm{PT}$ and APTT were significantly reduced with $(\mathrm{P}<0.05$, $<0.05)$ respectively [28]. The reduction in PT and APTT were expected in such women because the plasma concentration of several markers of coagulation including Factors VII, VIII, X,have been 
shown to be higher compared with non-users [2931]. Jose et al mentioned a significant decrease in APTT while Babatunde and Olaun observed a significant reduction in PT but there was no significant reduction in APT [32]. In our study the increase in these marker was non statistically significant and this result consist with study showed that although COCs containing desogestrel have been found to have an increased risk of VTE compared with those containing levonorgestrel or norethisterone, the desogestrel-only pill, Cerazette has not been associated with an increased risk. However, data are limited. A randomized, controlled, double-blind trial of desogestrel-only and levonorgestrel-only pills did not identify any clinically significant alterations in haemostatic parameters [33][34]. But disagree with Parasadet al.,(1999) who studied 67 healthy women who were randomly allocated to receive third generation gestodene (Gynera $\left.{ }^{\circledR}\right)$ or second generation levonorgestrel (Microgynon 30®) combination of low-dose estrogen oral contraceptives for their hemostatic effects over 2 years. Hemostatic changes were apparent within 3 months of OC use. Hematocrit was not affected, but hemoglobin concentration decreased by 18 months. Shortened prothrombin time and activated plasma thromboplastin time were associated with elevated fibrinogen within the 12-month use of both OCs. Factor VII was reduced only in Micro 30 during the 18 months of use. The underlying mechanisms of this response are unknown. Upon cessation, coagulation parameters returned to normal within 3 months [36].

\section{Conclusion:}

The result of this study indicate that the effect of combined oral contraceptives uses on prothrombin time, activated partial thromboplastin time and fibrinogenlevels are minor compared with control group.

Authors' contributions:

Dr. SawsanTalib Salman: Study design.

Dr. SawsanTalib Salman and Dr.RaakadKamelSaadi: Sample collection.

Dr. AreejAtiyah Hussein: Processing, Data analysis and manuscripts writing.

\section{References}

1.Tanis B.C. and Frits R.R. Venous and Arterial Thrombosis during Oral Contraceptive User Risks and Risk Factors. In Oral Contraceptives, Pregnancy, Hormone Replacement, and Thrombosis, Editor in Chief, Jan Jacques Michicls, Jan Rosing, and $\Gamma$ Eric Preston. Seminars $m$ VascuarMediane. Thieme Medical Publishers, Ine , 333 Seventh Avenue, New York, USA 2003; 3(1).

2. Moreau C, Trussell J, Rodriguez G, Bajos N, Bouyer. Contraceptive failure rates in France: results from a population-based survey.HumReprod. 2007;22(9):2422-7.
3. Abdalla TM, Kordofani AAY, Nimir AAH. Haemostatic studies in Sudanese women on oral contraceptive pills. Khartoum Medical Journal. 2008; 1(3):1.

4. Vandenbroucke JP, Jan $R$, Kitty WMB, SaskiaMiddeldorp, Frans MH, Bonno NB and Frits RR. Oral Contraceptives and the Risk of Venous Thrombosis.NEngl J Med 2001; 344:1527-1535.

5. Sagar S, Thomas DP, Stamatakis JD, Kakkar VV. Oral contraceptives, antithrombin III activity and postoperative deep-vein thrombosis. Lancet 1976; 1:509-11.

6. Guillebaud J. Surgery and the pill. BMJ. 1985;291:498-9.

7. Solymoss $S$. Risk of venous thromboembolism with oral contraceptives.CMAJ. 2011;183(18):E1278-9.

8. Jordan W. Pulmonary embolism. Lancet. 1961; 18:1146-7.

9.Odlind V, Milsom I, Persson I, Victor A. Can changes in sex hormone binding globulin predict the risk of venous thromboembolism with combined oral contraceptive pills? ActaObstetGynecol Scand. 2002; 81:482-90.

10. Vandenbroucke JP, Rosing J, Bloemenkamp KW, Middeldorp S, Helmerhorst FM, Bouma BN, Rosendaal FR. Oral contraceptives and the risk of venous thrombosis. N Engl J Med 2001;344:152735.

11. Pearce HM, Layton D, Wilton LV, Shakir SA. Deep vein thrombosis and pulmonary embolism reported in the Prescription Event Monitoring Study of Yasmin. Br J ClinPharmacol 2005; 60:98-102.

12. Legnani C, Palareti G, Guazzaloca G, Cosmi B, Lunghi B, Bernardi F, Coccheri S. Venous thromboembolism in young women; role of thrombophilic mutations and oral contraceptive use. Eur Heart J. 2002; 23 : 984-90.

13.Dacie SJ, Lewis SM. Practical haematology 5th ed. Edinburgh, London and New York, Churchill Livingstone, 2001:19.

14. Von-clauss A. gerinnungsphsioloischeschnell method zurbestimmung des fibrinogens. ActaHaematol (Basel) 1957;17:237-46.

15. Gaussem P, Alhenc-Gelas $M$, Thomas $J$, Remones $V$, Aiach $M$, Scarabin PY. Haemostatic effects of a new combined oral contraceptive, nomegestrol acetate/17beta-estradiol, compared with those of levonorgestrel/ethinyl estradiol. 2000. P131.

16. Machado RB, Nilson R D,Hugo M, Achilles MC. Effect of a continuous regimen of contraceptive combination of ethinylestradiol and drospirenone on lipid, carbohydrate and coagulation profiles. Contraception. 2010; 81: 102-106.

17. Walter B., Weiss C, Dorsch M, Bartsch P. Exercise-induced fibrin formation is enhanced in women using third-generation oral contraceptives. $J$ ThrombHaemost. 2006; 4:898-9.

18. Vlieg $A V$, Rosendaal FR. Interaction between oral contraceptive use and coagulation factor level in deep venous thrombosis. J ThrombHaemost. 2003; 1:2186-90. 
19. Robinson GE, Burren T, Mackie IJ, Bounds W, Walshe K, Faint R, Guillebaud J, Machin SJ. Changes in haemostasis after stopping the combined contraceptive pill: implications for major surgery. BMJ. 1991; 302(2):269-271.

20. Wilson ESB, Cruickshank J, Mcmaster M, Weir RJ. A prospective controlled study of the effect on blood pressure of contraceptive preparations containing different types and dosages of progestogen. International journal of Obstetrics and Gynecology. 1984; 91(12):1254-1260.

21. Khaw K, Peart WS. Blood pressure and contraceptive use. British medical journal. 1982; 285:403.

22.Salman ST, Basim MK, Areej AH. Expression of Lymphtoxin $\alpha$ and their Receptor among Aborted Women Infected with Human Cytomegalovirus. International Journal of Science and Research. 2017; 6(8):1395-1399.

23. LeBlanc ES, Ami L. Benefits and Risks of ThirdGeneration Oral Contraceptives. J Gen Intern Med. 1999; 14(10): 625-632.

24. Jespersen J. Pathophysiology and clinical aspects of fibrionolysis and inhibition of coagulation. Dan Med Bull 1988; 35:1-25.

25. Speroff L, DeCherney A. Evaluation of a new generation of oral contraceptives. The Advisory Board for New Progestions. ObstetGynecol 1993;81:1034-1047.

26. Van der Mooren MJ, Klipping C, Van Aken B, Helmerhorst E, Spielmann D, Kluft C. A comparative study of the effect of gestodene $60 \mathrm{mg}$ on hemostatic balance, blood lipid levels and carbohydrate metabolism. Eur J ContraceptReprod Health Care. 1999; 4 (Suppl 2):27-35.

27. Schindler AE. Differential effect of progestins on hemostasis. Maturitas. 2003; 46 (Suppl 1):S31-S37.

28. Klipping C, Joachim M. Effects of two combined oral contraceptives containing ethinyl estradiol 20 Ag combined with either drospirenone or desogestrel on lipids, hemostatic parameters and carbohydrate metabolism. Contraception 71 (2005) 409- 416.

29. Ibrahimi E, Mynyr K, Jurida A. Effect of a combined oral contraceptive containig $30 \mathrm{mg}$ ethinylestradiol and $75 \mathrm{mg}$ gestodene on haemostatic mechanisms in a group of albanian women. ICMBPS. 2013:271-274

30. Middeldorp S, Meijers JC, van den Ende AE, van Enk A, Bouma BN, Tans G, Rosing J, Prins MH, Büller HR. Effect on coagulation of levonorgestrel and desogestrel containing low dose oral contraceptive a cross-over Study. ThrombHaemost. 2000; 84(1):4-8.

31. Greta L, Hoetzer, Brian L. et al. Influence of oral contraceptive use endothelail t-PA release in healthy premonopausal women. Am J PhysiolEndocrinolMethal. 2003; 284: E90-E95.

32. Jose M, Luis C, Otavio C. et al. Effect of a combined oral contraceptive containing 20 microgethinyl estradiol and 75 microggestoden on haemostatic parameters. Gynecol Endocrinal. 2006; 62:41

33. Winkler UH, Howie H, Buhler K, Korver T, Geurts TB, CoelinghBennink HJ. A randomized controlled double-blind study of the effects on hemostasis of two progestogen-only pills containing 75 microgram desogestrel or 30 microgram levonorgestrel. Contraception. 1998; 57: 385-92.

34. Vasilakis C, Jick H, del Mar Melero-Montes M. Risk of idiopathic venous thromboembolism in users of progestagens alone. Lancet 1999; 354: 1610-1.

35. Parasad RNV, Stephen CL, Koh, Osbom AC. Effect on hemostasis after two year use of low dose combined oral contraceptives with gestodene or levonorgestrel. SAGE Journal. 1999; 5(1):

36. Speroff L, De Cherney A. Evaluation of a new generation of oral contraceptives The Advisory Board for the New ProgestmsObstet Gynecol. 1993,81: 1034-1047. 